\title{
Pengaruh Regional Spillover Terhadap PDRB Daerah Istimewa Yogyakarta Tahun 1996-2010
}

\author{
- Dityawarman El Aiyubbi * \\ Diana Wijayanti **
}

\begin{abstract}
aim

This study intends to determine effect of spillover regional to $P D R B$ in Yogyakarta form the year 1996 to 2010 . Yogyakarta has a very distinctive characteristics compared to other regions with the relatively low economic growth. As many as 15 years time series data used in this research that are consisted coninvestment, employment. Another data are number of economic data representing the industrial area variables, such as PDRB data of Klaten, Purworejo, Wonogiri, and Magelang Regeny which represents spillover regional.

The model is estimated using OLS (ordinary least squares).The results of the analysis of regional economic variables shows that the labor quantity is a significantly positive to PDRB of Yogyakarta, while investment and the number of industrial-are not significantly affect $P D R B$. The investment variable in PMA and PMDN data, turn out these investment flows occur in many activities that do not impact on the $P D R B$. While from the spillover of regional variables, it shows that only regencies that have similar economic characteristics that significantly influence the PDRB of Yogyakarta.
\end{abstract}

Kata kunci : Regional spillover, PDRB (Daerah Istimewa Yogyakarta, Klaten, Purworejo, Wonogiri, Magelang)

* Alumni Fakultas Ekonomi UII

** Dosen Fakultas Ekonomi UII 


\section{Pendahuluan}

Pembangunan daerah adalah suatu proses di mana pemerintah daerah dan masyarakatnya mengelola sumberdaya-sumberdaya yang ada dan membentuk suatu pola kemitraan antara pemerintah daerah dengan sektor swasta untuk menciptakan suatu lapangan kerja baru dan merangsang perkembangan kegiatan ekonomi (pertumbuhan ekonomi) dalam wilayah tersebut. Adapun tujuan dari pembangunan daerah adalah menciptakan pertumbuhan dan perubahan struktur ekonomi, perubahan sosial, mengurangi atau menghapuskan kemiskinan, serta mengurangi ketimpangan dan pengangguran. Sejalan dengan hal tersebut, maka pembangunan daerah menghendaki adanya kerjasama diantara pemerintah, sektor swasta dan masyarakat dalam mengelola sumber daya yang dimiliki oleh wilayah tersebut. Indikator keberhasilan pembangunan ditunjukkan oleh pertumbuhan ekonomi_dan berkurangnya ketimpangan baik di dalam distribusi pendapatan penduduk maupun antar wilayah.

Banyak teori dan studi menjelaskan bahwa pertumbuhan ekonomi dan pembangunan ekonomi dipengaruhi oleh modal fisik dan modal manusia serta teknologi (Todaro, 2000). Studi yang lain menyebutkan bahwa keterbukaan daerah (ekspor) juga akan mempercepat proses pembangunan ekonomi. Namun dewasa ini banyak ahli ekonomi kembali melakukan kajian terhadap faktor yang menentukan pertumbuhan ekonomi. Keadaan ini dilatarbelakangi oleh adanya fenomena dan perkembangan teori yang memasukkan faktor eksternalitas berupa inovasi (inovation), teknologi (technology), kreativitas (creativity), jejaring (networking) dan sumber daya manusia (SDM) sebagai mesin penggerak pertumbuhan ekonomi. 
Hal inilah yang kemudian menyebabkan daerah harus didorong untuk melakukan cross border spatial cooperation (kerjasama antar daerah/kota dan interregional) agar dapat meningkatkan aktivitas ekonomi. Selain itu daerah perlu menciptakan pusat-pusat pertumbuhan baru dengan memperhatikan efek dari pengaruh wilayah batas (regional spillover). Adapun bentuk hubungan antar daerah dalam bidang ekonomi dapat berupa arus atau aliran barang dan mata rantai pasar barang setengah jadi (intermediate goods) dan barang akhir (final goods), keterkaitan produksi, pola belanja konsumen (shopping), pola kontrol dan kepemilikan ekonomi, aliran pendapatan termasuk transfer dan pengiriman uang, aliran modal, sistem finansial baik formal maupun informal, migrasi tenaga kerja (employment migration) secara musiman dan komunikasi (communication)

Daerah Istimewa Yogyakarta sebagai salah satu propinsi di Indonesia, merupakan salah satu daerah yang memiliki karakterisktik khas dibandingkan dengan daerah-daerah lainnya. Secara geografis batas wilayah Daerah Istimewa Yogyakarta, pada sisi timur berbatasan dengan Kabupaten Klaten, pada sisi selatan berbatasan dengan wilayah Kabupaten Wonogiri, pada sisi barat berbatasan dengan wilayah Kabupaten Purworejo dan pada sisi utara berbatasan dengan wilayah Kabupaten Magelang. Wilayah Daerah Istimewa Yogyakarta, merupakan posisi yang strategis mengingat karakteristiknya sebagai kota pelajar menyebabkan hubungan dan mobilisasi penduduk dari wilayah lain sangat tinggi. Hal ini sangat menarik untuk mengetahui bagaimana pengaruh Regional Spillover terutama untuk daerah yang berbatasan secara langsungterhadap PDRB Daerah Istimewa Yogyakarta. 
Adapun tingkat pertumbuhan ekonominya, baik Daerah Istimewa Yogyakarta maupun daerah-daerah yang berbatasan secara dapat dilihat sebagai berikut:

Tabel :Pertumbuhan Ekonomi Propinsi di Pulau Jawa (dalam persen)

\begin{tabular}{|l|c|c|c|c|c|}
\hline Provinsi & 2004 & 2005 & 2006 & 2007 & 2008. \\
\hline DKI Jakarta & 5.65 & 6.01 & 5.95 & 6.44 & 6.22 \\
\hline Banten & 5.63 & 5.88 & 5.57 & 6.04 & 5.77 \\
\hline Jawa Barat & 4.77 & 5.6 & 6.02 & 6.48 & 5.84 \\
\hline Jawa Tengah & 5.13 & 5.35 & 5.33 & 5.59 & 5.46 \\
\hline DTY & 5.12 & 4.73 & 3.7 & 4.31 & 5.02 \\
\hline Jawa Timur & 5.83 & 5.48 & 5.8 & 6.11 & 5.94 \\
\hline
\end{tabular}

Sumber : BPS berbagai tahun terbitan

\section{Tinjauan Pustaka}

Berbagai pembahasan tentang Regional spillover sudah banyak dibicarakan dalam khasanah ekonomi regional pada beberapa dekade terakhir ini. Regional spillover pada dasarnya mengacu pada dinamika ekonomi dari suatu daerah yang dapat mempengaruhi daerah tetangganya melalui hubungan perdagangan dan hubungan pasar. Terjadinya kerjasama antar daerah serta penciptaan pusat-pusat pertumbuhan baru, dapat meningkatkan aktivitas ekonomi, yang akan memperluas dan dapat menjaga keberlangsungan perekonomian suatu daerah.

Pembahasan tentang dampak regional spillover terhadap pertumbuhan daerah diantaranya seperti yang di sebutkan oleh Fisher et all, (2002) dan Roomer (1990) yang menjelaskan pentingnya knowledge spillover bagi pertumbuhan daerah. Menurut mereka bahwa pengetahuan tidak semata-mata akan tetap berada dalam suatu daerah, tetapi akan menyebar ke wilayah lainnya. Roberta Capello (2012), juga menyebutkan pentingnya regional spillover bagi pertumbuhan daerah. Regional spillover ini meliputi knowledge spillover, industry spillover dan growth spillover. Penelitian-penelitian yang dilakukan oleh Yanging Jian (2012), 
Puman Ouyang, Shihe Fu (2012) di Cina dan Catherine Baumont, Cem Ertur and Julie Le Gallo (2001) di Eropa, menjelaskan tentang peranan faktor regional spillover di dalam pertumbuhan ekonomi suatu wilayah. Sementara Atilla Varga and Hans Joachim Scahalk (2004) juga menjelaskan tidak hanya regional spillover tetapi juga aglomerasi industri yang mempunyai peranan di dalam perekonomian makro yaitu di dalam penciptaan pertumbuhan ekonomi daerah. Di Indonesia penelitian tentang peranan regional spillover terhadap pertumbuhan ekonomi daerah juga telah dilakukan oleh I Wayan Suparta (2009). Hasil studinya yang mengambil kasus di propinsi Lampung menunjukkan bahwa pertumbuhan ekonomi di Lampung tidak hanya ditentukan oleh variabel-variabel makro daerah seperti investasi dan pengeluaran pemerintah, tetapi juga disebabkan oleh variabel regional spillover yaitu pendapatan dari daerah di sekitarnya, dalam hal ini adalah Propinsi DKI dan Sumatera Selatan. Disisi lain bila suatu daerah selalu mengandalkan daerah lain maka akan menciptakan ketergantungan terhadap daerah tetangga. Seperti teori yang dikembangkan Fingleton (2003) memperlihatkan bahwa terjadinya spillover dapat meningkatkan ketergantungan spasial tentang pertumbuhan suatu daerah.

Beberapa teori pertumbuhan daerah yang semua berangkat dari unbalanced growth secara implisit, sudah memasukkan konsep regional spillover. Teori-teori ini menjelaskan bahwa pertumbuhan akan selalu dimulai dari daerah yang menjadi pusat pertumbuhan, dan selanjutnya akan merembes ke daerah sekitarnya, sebagaimana dijelaskan dalam teori linkage effect dan industrial effect (Hirscman), core pheriphery model (Friedman), growth pole theory (Francois Perroux), dan beberapa teori pertumbuhan daerah lainnya. 
Teori Linkage Effect dan Industrial Effect (Hirscman) mengemukakan bahwa sekali pertumbuhan dimulai akan cenderung terkonsentrasi pada sekitar titik awal pertumbuhan yang disebabkan oleh ekonomi eksternal seperti biaya produksi yang lebih rendah, lokasi perusahaan yang berkaitan ekspansi pasar. Daerah lain akan menerima efek positif dan negatif dari wilayah yang menjadi titik pertumbuhan secara geografis. Hirschman menyebut efek yang menguntungkan sebagai trickling down forces dan efek merugikan sebagai polarization effect.

Pengembangan teori-teori pertumbuhan dan pembangunan daerah selanjutnya masih berlandaskan pada konsep unbanced growth, sebagaimana teori Core Periphery yang dikembangkan oleh John Friedman (1966) yang menyatakan bahwa daerah itu terbagi menjadi dua bagian besar, yaitu pusat yang dinanis (core)dan pinggiran yang statis (phery). Teori ini menekankan bahwa ada hubungan yang erat antara daerah pusat yang dinamis (kota) dan derah pinggiran yang statis (desa). Ferkembangan daerah perkotaan akan sangat ditentukan oleh daerah di sekitarnya. Sebaliknya perkembangan daerah pedesaan juga akan sangat dipengaruhi oleh daerah perkotaan.

Growth Pole Theory yang dikembangkan oleh Francois Perroux, (1950) menjelaskan bahwa kegiatan ekonomi tidak terjadi di seluruh wilayah, tetapi terpusat pada wilayah-wilayah tertentu. Teori ini juga menjelaskan peranan aglomerasi industri sebagai faktor pendorong terjadinya perkembangan daerah, karena dampak dari pengelompokan industri ini akan memberi spillover (luberan) di daerah sekitarnya, sehingga akan mendorong terjadinya perkembangan wilayah.

Teori basis ekspor (Export based theory) yang dikembangkan oleh Richardson. Teori ini menjelaskan bahwa sistem regional menjadi dua bagian yaitu daerah yang bersangkutan dan daerah-daerah 1782 
lainnya.Sebagai suatu sistem,' keseluruhan masyarakat melakukan perdagangan dengan masyarakat lain di luar batas wilayahnya. Faktor penentu pertumbuhan ekonomi (sektor basis) dikaitkan secara langsung kepada permintaan akan barang dari daerah lain (ekspor) di luar batas masyarakat ekonomi regional. Dengan demikian terjadinya proses perdagangan yang dilakukan antar daerah, akan dapat mendorong pertumbuhan ekonomi.

\section{Hipotesis}

Hipotesis dalam penelitian ini adalah:

1. Diduga modal (PMDN dan PMA) berpengaruh positif terhadap PDRB daerah Daerah Istimewa Yogyakarta

2. Diduga angkatan kerja berpengaruh positif terhadap PDRB daerah Daerah Istimewa Yogyakarta

3. Diduga jumlah industri berpengaruh positif terhadap PDRB daerah Daerah Istimewa Yogyakarta

4. Diduga regional spillover, yaitu PDRB daerah yang berbatasan dengan Därah Istimeẉa Yogyakarta (Kabupaten Klaten, Wonogiri, Purwerejo dan Magelang) berpengaruh positif terhadap PDRB daerah Daerah Istimewa Yogyakarta

\section{Metode Penelitian}

\section{Data Penelitian}

Penelitian ini menggunakan data sekunder dalam bentuk deret waktu (time serieas) selama 15 tahun dari 1996-2010 yang diperoleh diperoleh dari BPS yang diolah dari berbagai tahun. Adapun variabel dependen (Y) yang dipakai adalah data PDRB Daerah Istimewa 
Yogyakarta, sedangkan varibel independennya $(\mathrm{X})$ dibedakan menjadi dua, yaitu:

1. Variabel-variabel yang mewakili ekonomi daerah, yang terdiri dari:

a. Data Investasi : Data PMA dan PMDN Daerah Istimewa Yogyakarta.

b. Jumlah angkatan kerja di Daerah Istimewa Yogyakarta.

c. Jumlah industri Daerah Istimewa Yogyakarta

d. Variabel yang mewakili regional spillover yaitu dengan menggunakan data PDRB dari daerah yang berbatasan langsung dengan Daerah Istimewa Yogyakarta, antara lain: PDRB Kabupaten Klaten, PDRB Kabupaten Wonogiri, PDRB Kabupaten Purworejo dan PDRB Kabupaten Magelang

\section{Alat Analisis}

Alat analisis yang dipakai dalam penelitian ini adalah model regresi berganda. Model Regresi berganda merupakan metode statistika yang dipakai untuk mengetahui pola hubungan antar variabel. Model regresi ini terdiri lebih dari satu variabel independen. Adapun bentuk umum regresi berganda :

$$
Y_{i}=\beta_{0}+\beta_{1} X_{1 i}+\beta_{2} X_{2 i}+\ldots \ldots+\beta_{k} X_{k i}+e_{i}
$$

Dimana $Y$ merupakan variabel independen dan $X_{1}, X_{2}$, merupakan variabel independen.Adapun bentuk persamaan regresi dalam penelitian ini adalah:

$$
Y=\beta_{0}+\beta_{1} X_{1}+\beta_{2} X_{2}+\beta_{3} X_{3}+\beta_{4} X_{4}+\beta_{5} X_{5}+\beta_{6} X_{6}+\beta_{7} X_{7}+\beta_{8} X_{8+} e_{i}
$$

\section{Dimana:}

$\mathrm{Y}$ adalah PDRB di Daerah Istimewa Yogyakarta ; X1 adalah. PMDN di Daerah Istimewa Yogyakarta ; X2 adalah PMA di DaerahIstimewa Yogyakarta ; X3 adalah jumlah angkatan kerja di Daerah Istimewa Yogyakarta ; X4 adalah jumlah industri di Daerah Istimewa Yogyakarta ; 1784 
X5 adalah PDRB Kabupaten Klaten ; X6 adalah PDRB Kabupaten Wonogiri ;X7 adalah PDRB Kabupaten Purworejo ; X8 adalah PDRB Kabupaten Magelang

Untuk menilai apakah model regresi yang dihasilkan merupakan model yang paling sesuai (memiliki error terkecil), dibutuhkan beberapa pengujian dan analisis diantaranya adalah uji $t$, uji $F$ serta uji asumsi klasik yang mencakup uji multikolinearitas, uji heterokedastisitas dan uji autokorelasi.

\section{Analisis Data}

Penelitian ini menggunakan uji Mc Kinnon, White dan Davidson atau yang lebih dikenal dengan uji MWD. Model ini bertujuan untuk memilith antara model regresi linier dan model regresi log linier sehingga mendapatkan hasil regresi terbaik.

Berdasarkan hasil estimasi nilaị $Z_{1}$ adalah -2.58 sedangkan nilai $t$ kritis pada $\alpha=5 \%$ dengan df 5 adalah -2.571 karena $t$ hitung $>$ dari $t$ kritis maka $Z_{1}$ signifikan sehingga menerima hipotesis nol. Sedangkan $Z_{2}$ adalah -0.32 sedangkan nilai $\mathrm{t}$ kritis pada $\alpha=5 \%$ dengan df 5 adalah 2.571 karena $\mathrm{t}$ hitung < dari $\mathrm{t}$ kritis maka $\mathrm{Z}_{2}$ tidak-signifikan sehingga menerima hipotesis alternatif. Maka dengan derajat kepercayaan $95 \%$ ( $\alpha$ $=5 \%$ ) bentuk fungsi log linier lebih baik dari pada fungsi linier. Sehingga model regresi yang digunakan adalah fungsi log linier. $\ln \mathrm{Y}_{\mathrm{i}}=\beta_{0}+\beta_{1} \ln \mathrm{X}_{\mathrm{i}}+\beta_{2} \ln \mathrm{X}_{2}+\beta_{3} \ln \mathrm{X}_{3}+\beta_{4} \ln \mathrm{X}_{4}+\beta_{5} \ln \mathrm{X}_{5}+\beta_{6} \ln \mathrm{X}_{6}+\beta_{7}$ $\ln \mathrm{X}_{7}+\beta_{8} \ln \mathrm{X}_{8}+\mathrm{v}_{\mathrm{t}}$

Hasil estimasi sebagai berikut :

$\ln Y_{i}=1.604531+0.008230 \ln X_{i}+0.001933 \ln X_{2}-0.167354 \ln X_{3}+$ $0.000507 \ln \mathrm{X}_{4}$ 


\section{$(0.053454)$}

$\begin{array}{llll}(2.547807) & (0.729770) & (0.461174) & (-2.996354)\end{array}$

$+0.605067 \ln \mathrm{X}_{5}+0.282828 \ln \mathrm{X}_{6}+0.173898 \ln \mathrm{X}_{7}+0.100383 \ln \mathrm{X}_{8}+\mathrm{v}_{\mathrm{t}}$

$\begin{array}{llll}(9.278941) & (1.252709) \quad(0.604081) & (0.422652)\end{array}$

Dimana :

( ) adalah nilai $\mathrm{t}$ hitung, R-Square $=0.999774$, R-Square Adjusted $=$ $0.999472, F=3316.102$, Durbin-Watson $(D-W)=3.325760$,

Sumber: Pengolahan data hasil penelitian

Hasil dari estimasi model $\log$ linier menghasilkan $\mathrm{R}^{2}$ sebesar 0.999774 artinya bahwa $99.97 \%$ variasi variabel dependen (PDRB DI Yogyakarta) dapat dijelaskan oleh variabel independent (PMDN di Daerah Istimewa Yogyakarta,PMA Daerah Istimewa Yogyakarta, jumlah angkatan kerja di Daerah Istimewa Yogyakarta, jumlah industri di Daerah Istimewa Yogyakarta, PDRB Kabupaten Klaten, PDRB Kabupaten Wonogiri, PDRB Kabupaten Purworejo, PDRB Kabupaten Magelang), sedangkan sisanya sebesar $0.03 \%$ dijelaskan oleh variabel lain diluar model.

Untuk mengetahui tingkat signifikansi dari koefisien determinasi ini maka diuji dengan menggunakan uji masing-masing variabel atau uji t maupun uji bersama atau uji F. Hasil pengolahan data didapatkan nilai thitung untuk variabel PMDN sebesar 0.729770 sedangkan untuk nilai $t$ tabel uji dua sisi dengan derajat kebebasan 6 dan $\alpha=5 \%$ maka diperoleh nilai sebesar 2.447. Karena t-hitung lebih kecil dari t-tabel maka variabel PMDN tidak berpengaruh terhadap PDRB Daerah Istimewa Yogyakarta.

Hasil pengolahan data didapatkan nilai t-hitung untuk variabel PMA sebesar 0.461174 sedangkan untuk nilai t tabel uji dua sisi dengan derajat kebebasan 6 dan $\alpha=5 \%$ maka diperoleh nilai sebesar 2.447 . 
Karena t-hitung lebih kecil dari t-tabel maka variabel PMA tidak berpengaruh terhadap PDRB Daerah Istimewa Yogyakarta. Nilai t-hitung variabel jumlah angkatan kerja sebesar -2.996354 , nilai t tabel uji dua sisi dengan derajat kebebasan 6 dan $\alpha=5 \%$ maka diperoleh nilai sebesar 2.447. Karena t-hitung lebih besar dari t-tabel maka variabel jumlah angkatan kerja berpengaruh negatif terhadap PDRB Daerah Istimewa Yogyakarta.

Nilai t-hitung untuk variabel jumlah industri sebesar 0.053454 sedangkan untuk nilai $t$ tabel uji dua sisi dengan derajat kebebasan 6 dan $\alpha=5 \%$ maka diperoleh nilai sebesar 2.447. Karena t-hitung lebih kecil dari t-tabel maka variabel jumlah industri tidak berpengaruh terhadap PDRB Daerah Istimewa Yogyakarta. Nilai t-hitung untuk variabel Kabupaten Klaten sebesar 9.278941 sedangkan untuk nilai $t$ tabel uji dua sisi dengan derajat kebebasan 6 dan $\alpha=5 \%$ maka diperoleh nilai sebesar 2.447. Karena t-hitung lebih besar dari t-tabel maka variabel Kabupaten Klaten berpengaruh positif terhadap PDRB Daerah Istimewa Yogyakarta. Nilai t-hitung untuk variabel Kabupaten Wonogiri sebesar 1.252709 sedangkan untuk nilai $t$ tabel uji dua sisi dengan derajat kebebasan 6 dan $\alpha=5 \%$ maka diperoleh nilai sebesar 2.447. Karena t-hitung lebih kecil dari t-tabel maka variabel Kabupaten Wonogiri tidak berpengaruh terhadap PDRB Daerah Istimewa Yogyakarta.

Nilai t-hitung untuk variabel Kabupaten Purworejo sebesar 0.604081 sedangkan untuk nilai $t$ tabel uji dua sisi dengan derajat kebebasan 6 dan $\alpha=5 \%$ maka dipèroleh nilai sebesar 2.447. Karena $t-$ hitung lebih kecil dari t-tabel maka variabel Kabupaten Purworejo tidak berpengaruh terhadap PDRB Daerah Istimewa Yogyakarta. Nilai t-hitung untuk variabel Kabupaten Magelang sebesar 0.422652 sedangkan untuk 
nilai $t$ tabel uji dua sisi dengan derajat kebebasan 6 dan $\alpha=5 \%$ maka diperoleh nilai sebesar 2.447. Karena t-hitung lebih kecil dari t-tabel maka variabel Kabupaten Magelang tidak berpengaruh terhadap PDRB Daerah Istimewa Yogyakarta. Nilai F-hitung sebesar 3316.102 sedangkan nilai F-tabel sebesar 4.15. Karena F-hitung lebih besar dari F-tabel berarti semua variabel yang diamati dalam penelitian ini berpengaruh nyata terhadap PDRB Daerah Istimewa Yogyakarta

Analisis ekonomi secara parsial terhadap variabel-variabel ekonomi yang mempengaruhi PDRB Daerah Istimewa Yogyakarta adalah sebagai berikut:

\section{Pengaruh PMDN di Daerah Istimewa Yogyakarta terhadap PDRB DI \\ Yogyakarta}

Berdasarkan uji hipotesis, nilai penanaman modal dalam negeri tidak berpengaruh terhadap PDRB Daerah Istimewa Yogyakarta. Di DI Yogyakarta sendiri kebijakan tentang penanaman modal telah diataur salah satu kebijakan tersebut adalah tidak diperuntukan bagi industri besar. Bidang usaha dari PMDN itu adalah perdaganga eceran skala kecil (mini market) dan industri mesin pertanian.

Pada tahun 2006, pengusaha mikro dan kecil memperoleh bantuan dari pemerintah kota Yogyakarta melalui Dinas Perindagkop melalui kegiatan Pemberdayaan Ekonomi Berbasis Kewilayahan (PEW). Hingga tahun 2010, sebanyak 922 kelompok telah mendapatkan penguatan modal dalam bentuk bantuan dana bergulir.

Di Daerah Istimewa Yogyakarta sendiri PMDN tidak berpengaruh karena bidang usaha PMDN diperuntukan untuk industri kecil. Industri kecil hanya berpengaruh terhadap penyerapan tenaga kerja sehingga apabila PMDN naik tidak akan berpengaruh terhadap PDRB. 


\section{Pengaruh PMA di Daerah Istimewa Yogyakarta terhadap PDRB DI}

\section{Yogyakarta}

Berdasarkan uji hipotesis, nilai penanaman modal asing tidak berpengaruh terhadap PDRB Daerah Istimewa Yogyakarta. Tidak jauh berbeda dengan PMDN, jumlah perusahaan PMA masih tergolong minim yaitu 16 pada tahun 2008, sulitnya perizinan dan perusahaan PMA harus berbadan hukum PT merupakan kendala utama minimnya perusahaan PMA. Bidang usaha PMA terdiri dari berbagai bidang usaha mulaidari industri pakaian jadi dari tekstil, barang dari plastik serta perdagangan ekspor hinggaindustri kosmetik, jasa kebugaran serta perdagangan ekspor dan impor. Bidang usahanya pun diperuntukan untuk industri kecil, sehingga tidak berpengaruh terhadap PDRB.

\section{Jumlah angkatan kerja di Daerah Istimewa Yogyakarta terhadap PDRB DI Yogyakarta}

Berdasarkan uji hipotesis, nilai angkatan kerja berpengaruh negatif terhadap PDRB Daerah Istimewa Yogyakarta. Hal ini disebabkan oleh semakin meningkatnya jumlah angkatan kerja setiap tahunnya sehingga menyebabkan peluang akan pengangguran juga semakin tinggi. Karena terkadang kesempatan kerja tidak mampu menampung jumlah angkatan kerja baru sehingga berpotensi meningkatnya jumlah pengangguran. Demikian juga yang terjadi di Daerah Istimewa Yogyakarta, jumlah angkatan kerja yang semakin meningkat tetapi berpeluang juga meningkatnya jumlah pengangguran. Pernyataan tersebut didukung oleh data yang dikeluarkan BPS, pada tahun 2010 jumlah angkatan kerja yang ada di DIY mencapai 2,07 juta orang. Jumlah itu bertambah sekitar 50 ribu orang dibanding angkatan kerja pada Agustus 2009 yang sebanyak 
2,02 juta orang. Peningkatan jumlah angkatan kerja diikuti dengan peningkatan jumlah pengangguran yaitu pada Februari 2010 diketahui jumlah pengangguran di DIY meningkat hingga 3.300 orang dibandingkan tahun 2009 lalu.Dengan semakin tingginya jumlah pengangguran maka akan berpengaruh negatif terhadap PDRB DI Yogyakarta karena peningkatan jumlah pengangguran akan menjadi beban tersendiri bagi suatu daerah.

\section{Jumlah industri di Daerah Istimewa Yogyakarta terhadap PDRB DI}

\section{Yogyakarta}

Berdasarkan uji hipotesis, nilai jumlah industri tidak berpengaruh terhadap PDRB Daerah Istimewa Yogyakarta. Karena jumlah industri yang terdapat di Daerah Istimewa Yogyakarta didominasi oleh industri kecil atau industri rumahan dibandingkan industri besar dan menengah, selain itu PMA dan PMDN diperuntukan untuk industri kecil sehingga indusiri besar dan menengah tidak menerima permodalan. Hal ini menyebabkan industri besar dan menengah kurang berpengaruh terhadap PDRB Daerah Istimewa Yogyakarta.

\section{PDRB Kabupaten Klaten terhadap PDRB DI Yogyakarta}

Berdasarkan uji hipotesis, nilai PDRB Kabupaten Klaten berpengaruh positif terhadap PDRB Daerah Istimewa Yogyakarta. Hal ini disebabkan adanya timbal balik antara industri di Klaten dan Daerah Istimewa Yogyakarta, nilai produksi yang paling tinggi di Klaten adalah industri konveksi / pakaian jadi. Tidak jarang bahan baku maupun barang jadi dari industri tersebut didapatkan dari Daerah Istimewa Yogyakarta, kemudian diolah menjadi pakaian jadi dan dijual lagi keberbagai daerah termasuk Daerah Istimewa Yogyakarta itu Sendiri. Selain itu bila dilihat dari kondisi geografis Kabupaten Klaten sebelah barat dan selatan 1790 
berbatasan langsung dengan Daerah Istimewa Yogyakarta sehingga wajar bila PDRB Kabupaten Klaten berpengaruh terhadap PDRB Daerah Istimewa Yogyakarta.

\section{PDRB Kabupaten Wonogin terhadap PDRB DI Yogyakarta}

Berdasarkan uji hipotesis, nilai Kabupaten Wonogiri tidak berpengaruh terhadap PDRB Daerah Istimewa Yogyakarta. Hal ini disebabkan Kabupaten Wonogiri ingin meningkatkan perekonomiannya ataupun pendapatan daerahnya dengan memanfaatkan potensi sumber daya alam yang dimiliki, seperti kacang mete, jamu tradisional, bahan permata, industri karoseri. Dengan komitmen Kabupaten Wonogiri yang ingin memanfaatkan potensi SDA sehingga tidak tergantung daerah lain. Sangat wajar bila PDRB Kabupaten Wonogiri tidak berpengaruh terhadap PDRB Daerah Istimewa Yogyakarta.

\section{PDRB Kabupaten Purworejo terhadap PDRB DI Yogyakarta}

Berdasarkan uji hipotesis, nilai Kabupaten Purworejo tidak berpengaruh terhadap PDRB Daerah Istimewa Yogyakarta. Hal ini dikarenakan Purworejo memiliki industri yang sedang naik daun hingga pasarannya menenbus mancanegara. Selain itu pada tahun 2007 telah berdiri cabang dari rokok sampurna. Melihat pesatnya perkembangan industri di Purworejo sehingga wajar bila PDRB Kabupaten Purworejo tidak berpengaruh terhadap PDRB Daerah Istimewa Yogyakarta.

\section{PDRB Kabupaten Magelang terhadap PDRB DI Yogyakarta}

Berdasarkan uji hipotesis, nilai Kabupaten Magelang tidak berpengaruh terhadap PDRB Daerah Istimewa Yogyakarta. Bila dilihat, nilai PDRB Kabupaten Magelang cukup besar tetapi tidak berpengaruh terhadap PDRB Daerah Istimewa Yogyakarta. Hal ini disebabkan Kabupaten Magelang memiliki obyek wisata yang tidak sedikit 
menyumbang dalam pertumbuhan ekonomi di Kabupaten Magelang. Dari segi perkebunan, tanaman kopi sangat menonjol karena dikembangkan secara khusus sejak tahun 2004. Sektor pertanian merupakan pendukung pertumbuhan ekonomi Kabupaten Magelang. Bila dilihat dari kondisi geografis pusat pertumbuhan ekonomi Kabupaten Magelang sangat jauh dari Daerah Istimewa Yogyakarta. Sehingga PDRB kabupaten Magelang tidak berpengaruh terhadap PDRB Daerah Istimewa Yogyakarta.

Jadi Regional Spillover terjadi pada daerah yang memiliki kesamaan struktur ekonomi seperti yang terjadi di Daerah Istimewa Yogyakarta dan Kabupaten Klaten.

\section{Kesimpulan Dan Saran}

Berdasarkan hasil dan analisis, maka dapat disimpulkan sebagai berikut :

1. Variabel PMDN tidak berpengaruh terhadap PDRB DIY. Variabel PMDN tidak sesuai dengan hipotesis yang menyatakan adanya hubungan positif antara PMDN dan PDRB DTY. Hal ini disebabkan karena industri kecil belum terakomodir dalam hal memperoleh modal. Bidang usaha PMDN masih terbatas pada mini market dan industri mesin pertanian.

2. Variabel PMA tidak berpengaruh terhadap PDRB DIY. Variabel PMA tidak sesuai dengan hipotesis yang menyatakan adanya hubungan positif antara PMA dan PDRB DIY. Hal ini terjadi karena bidang usaha PMA masih tergolong industri menengah sehingga industri kecil tidak terakomodir dengan baik. Ini tidak jauh berbeda dengan PMDN.

3. Variabel angkatan kerja berpengaruh negatif terhadap PDRB DI yogyakarta. Variabel angkatan kerja tidak sesuai dengan hipotesis yang menyatakan adanya hubungan positif antara angkatan kerja dan 1792 
PDRB DI Yogyakarta. Hal ini terjadi karena apabila jumlah angkatan kerja meningkat tetapi tidak diimbangi dengan jumlah lapangan kerja maka akan menyebabkan jumlah pengangguran meningkat. Dengan semakin tingginya jumlah pengangguran maka akan berpengaruh negatif terhadap PDRB DI Yogyakarta karena peningkatan jumlah pengangguran akan menjadi beban tersendiri bagi suatu daerah.

4. Variabel jumlah industri tidak berpengaruh terhadap PDRB DIY. Variabel jumlah industri tidak sesuai dengan hipotesis yang menyatakan adanya hubungan positif antara jumlah industri dan PDRB DI Yogyakarta. Penolakan ini terjadi karena di DI Yogyakarta didominasi oleh industri kecil atau rumahan, selain itu PMA dan PMDN diperuntukan untuk industri kecil sehingga industri besar dan menengah tidak menerima permodalan. Hal ini menyebabkan industri besar dan menengah tidak berpengaruh.

5. Variabel PDRB Kabupaten Klaten berpengaruh terhadap PDRB DI Yogyakarta. Variabel PDRB Kabupaten Klaten sesuai dengan hipotesis yang menyatakan adanya hubungan positif antara PDRB - Kabupaten Klaten dan PDRB DI Yogyakarta. Hal ini dikarenakan adanya kesamaan jenis industri yang menyebabkan adanya timbal balik dari kedua daerah tersebut.

6. Variabel PDRB Kabupaten Wonogiri tidak berpengaruh terhadap PDRB DI Yogyakarta. Variabel PDRB Kabupaten Wonogiri tidak sesuai dengan hipotesis yang menyatakan adanya hubungan positif antara PDRB Kabupaten Wonogiri dan PDRB DI Yogyakarta. Ini disebabkan karena komitmen Kabupaten Wonogiri yang ingin memanfaatkan potensi SDA sehingga tidak tergantung daerah lain. 
Sangat wajar bila PDRB Kabupaten Wonogiri tidak berpengaruh terhadap PDRB Daerah Istimewa Yogyakarta.

7. Variabel PDRB Kabupaten Purworejo tidak berpengaruh terhadap PDRB DI Yogyakarta. Variabel PDRB Kabupaten Purworejo tidak

- sesuai dengan hipotesis yang menyatakan adanya hubungan positif antara PDRB Kabupaten Purworejo dan PDRB DI Yogyakarta. Penolakan ini terjadi karena tidak adanya kesamaan dari jenis industri sehingga tidak ada timbal balik dari kedua daerah tersebut. Seperti yang dapat kita lihat Kabupaten Purworejo memiliki indutri besar seperti pabrik rokok Sampurna.

8. Variabel PDRB Kabupaten Magelang tidak berpengaruh terhadap PDRB DI yogyakarta. Variabel PDRB Kabupaten Magelang tidak sesuai dengan hipotesis yang menyatakan adanya hubungan positif antara PDRB Kabupaten Magelang dan PDRB DI Yogyakarta. Hal ini disebabkan karena bila dilihat dari kondisi geografis pusat pertumbuhan ekonomi Kabupaten Magelang sangat jauh dari Daerah Istimewa Yogyakarta. Selain itu faktor pendorong meningkatnya pertumbuhan ekonomi seperti obyek wisata tidak memiliki hubungan timbal balik terhadap DI Yogyakarta.

Ada beberapa implikasi yang diperoleh dari dari penelitian ini, yaitu :

1. Diperlukan perhatian pada sektor permodalan baik PMDN maupun PMA, seharusnya PMA atau PMDN tidak hanya diperuntukkan untuk industri kecil saja. Industri besar dan menengah juga perlu dipertimbangkan untuk menerima PMA atau PMDN.

2. Memperluas lapangan kerja sehingga mampu menampung angkatan kerja baru sehingga dapat mengurangi tingkat pengangguran.

3. Perlu diperhatikannya industri besar dan menengah dalam hal permodalan. 
4. Diperlukan adanya kerja sama anatar daerah agar terciptanya hubungan timbal balik sehingga meningkatkan pertumbuhan ekonomi daerah seperti teori yang dikemukakan oleh Richardson dan John Friedman. 


\section{DAFTAR PUSTAKA}

Baumont, C., Ertur, C. \& Le Gallo, J. (2001). A Spatial Econometric Analysis of Geographic Spillovers and Growth for European Regions.

Bendavid, V. A. (1991). Regional and Local Economy Analysis for Practitioners. New York: Greenwood Publishing Group. Inc.

Brochner, M. J. (2005). Technology Spillover Through Trade and TFP Convergence: 120 Years of Evidence for the OECD Countries.

Chen, Y. \& Wu, Y. (2012). Regional Economic Growth and Spillover Effect: An Analysis of China's Pan Pearl River Delta Area, China and World Economy. Jurnal Vol 20, Issue 2, pp. 80-97.

Dinas Perindustrian Perdagangan Koperasi dan Pertanian Kota Yogyakarta. PEW 2011. Diakses pada tanggal 8 September 2012 dari http://umkm.jogjakota.go.id/direktori/

Ding, D. \& Masha, I. (2012). India's Growth Spillovers to Shouth Asia. IMF Working Paper, WP/12/56.

Erawatyyenny's Blog. Permasalahan Ekonomi dan Sumber Daya Alam di Kabupaten Magelang. Diakses pada tanggal 14 Agustus 2012 dari situs http://erawatyyenny.wordpress.com/2010/01/02/

permasalahan-ekonomi-dan-sumber-daya-alam-di-kabupaten-magelang/

Fisher, M. (2006). Innovation, Network and Knowledge Spillover: Selected Essay, Springer. Verlag, Berlin.

Jakarta Business Sevices. Diakses pada tanggal 18 Agustus 2012 dari situs http://www.jbs.co.id/penanaman-modal-asing-pmamenuperijinan-95.html

Jakarta Business Sevices. Diakses pada tanggal 18 Agustus 2012 dari situs http://www.jbs.co.id/penanaman-modal-dalam-negeri-pmdnmenuperijinan-96.html.

Kajian Ekonomi Regional. Diakses pada tanggal 7 April 2012 dari situs www.bi.go.id.

Luo, X. (2005). Growth Spillover Effect And Regional Development Patterns: The Case of Chinese Provinces. World Bank Policy Research Working Paper 3652.

Nurhadi. Strategi Perencanaan Pembangunan Regional dalam Kajian Variasi Keruangan. Skripsi. Universitas Negeri Yogyakarta.

Ouyang, P. \& Fu, S. (2012). Economic Growth, Industrial Development and Inter-Regional-Spillovers from Foreign Direct Investment: Evidence from China.

Pemerintah Kabupaten Purworejo. Diakses pada tanggal 14 Agustus 2012 dari situs http://id.wikipedia.org/wiki/Kabupaten_Purworejo. 
Pemerintah Kabupaten Wonogiri. Diakses pada tanggal 14 Agustus 2012 dari situs http://www.wonogirikab.go.id/home.php.

Sudamono, M. (2006). Analisis Transformasi Struktural, Pertumbuhan Ekonomi dan Ketimpangan antar Daerah Di Wilayah Pembangunan 1 Jateng. Skripsi. Universitas Diponogoro.

Suparta, W. (2009). Spillover Effect Perekonomian Provinsi DKI Jakarta - dan Sumatera Selatan Terhadap Pertumbuhan Ekonomi Provinsi Lampung. Jurnal Ekonomi Pembangunan, Vol. 10, No. 1, hal 3241.

Urusan Penanaman Modal. Diakses pada tanggal 8 September 2012 dari http://dppka.jogjaprov.go.id/document/9.\%20Urusan\%20Penanam an\%20Modal-OK.pdf.

Varga, A. \& Scahalk, H. J. (2004). Knowledge Spillover, Agglomeration and Economic Macro Growth, an empirical approach. CREP

-- working paper.

Widarjono, Agus. (2009). Ekonometrika Pengantar dan Aplikasinya. Yogyakarta: Ekonisia.

Yanqing, J. Urban \& Regional Development Studies. Jurnal Vol 2

Republika Online. Selasa, 23 November 2010, 23:31 WIB. Pengangguran Di Yogyakarta Terus Meningkat. Diakses pada $\begin{array}{lllll}\text { tanggal } & 8 & \text { September } & 2012 & \text { dari }\end{array}$ http://www.republika.co.id/berita/breakingnews/nusantara/10/11/23/148299-pengangguran-di-yogyakarta-terusmeningkat 
